\author{
BORO BRONZA \\ University of Banja Luka \\ Faculty of Philosophy, Department of History \\ boro.bronza@unibl.rs
}

\title{
AUSTRIAN TRADE TOWARDS THE OTTOMAN EMPIRE AND ASIA DURING THE $18^{\text {th }}$ CENTURY
}

\begin{abstract}
After geographical discoveries of the 15th and 16th centuries the economic system based on trade began to develop in the real sense at the planetary level. During the 18th century, just before the start of the industrial revolution, the system experienced a peak. Naval powers played a key role in its global development, as their commercial and military fleets enabled the constant fluctuation of the goods on all oceans and continents. The trade of European naval forces with India and other parts of Asia was particularly significant regarding the commercial aspects and large profits were achieved especially in the triangle of slave trade between Europe, Africa and America. In this context Austria was mostly just an observer because its effect on the global commercial efforts was dominantly continental. However, with the development of the 18thcentury Austria invested also more efforts to increase its share in the global trade and the accumulation of trade capital. The Court Chamber was efficiently organized for the new conditions of economic activity in 1714 through a thorough set of reforms. The division of chambers into independent commissions was fully achieved. It was an adequate administrative basis for the start of the Austrian trade expansion to the east and southeast throughout the rest of the 18th century.
\end{abstract}

Keywords: Austria, Ottoman Empire, Asia, India, economy, trade, mercantilism, mercury, Trieste, Rijeka (Fiume), William Bolts.

t the beginning of the $18^{\text {th }}$ century the mercantilist principles of economy started to
play a crucial role in Austrian efforts towards new dimensions of development.
Therefore, for Austria, this was the time for the real implementation of 'The Age
of the territorial economy' ('Zeitalter der Territorialwirtschaft'). Due to the French model
around the end of $17^{\text {th }}$ century mercantilism in Austria was often referred to as
'Colbertismus'..$^{1}$ But later on, during the $18^{\text {th }}$ century mercantilism in the Habsburg lands
was mainly defined as 'Cameralism'. Over time cameralism became a specific Austrian
kind of mercantilism, which further emphasized the influence of the state in the
implementation of economic principles in relation to the private sector, where this kind of

${ }^{1}$ Srbik 1907: 19. 
influence was generally much stronger than in the more classical forms of Western mercantilism. It was a revolutionary change in the system of priorities of the Habsburg policies, set in line with increasingly relevant and commonly accepted attitudes of European philosophers that in the $18^{\text {th }}$ century 'money replaced God'. ${ }^{2}$ However, the Habsburg Monarchy was a state which was too predominantly based on metaphysical concepts of the royal government to be able to quickly put into effect this kind of a total financial and ideological transformation.

Chronologically speaking, the real beginning of the era of mercantilism in Austria was related to the suppression of the Ottoman Empire at the time of the Vienna War (1683-1699) and the development of attitudes of the founder of the Austrian mercantilist theory and later practice, Johann Joachim Becher (1635-1682). Becher was the first to understand the idea of the necessity of an 'egoistic state action', which was the core of the mercantilist system. ${ }^{3}$ For a proper implementation of such an approach the access to as many people as possible was a necessary prerequisite. ${ }^{4}$ Essentially mercantilists urged the need for a demographic revolution, mainly by attracting more people from other countries. Accordingly, 'ubi populus, idi obulus' became the basic maxim of Austrian cameralism. ${ }^{5}$ The development of such principles further increased the development of the national spirit, which also happened in France during the second half of the $17^{\text {th }}$ century. In this context particularly significant was the merit of the German mathematician and philosopher Gottfried Wilhelm Leibniz (1646-1716), who used to live and work in Vienna for several years (1712-1714). At the end of the $17^{\text {th }}$ century, under the influence of mercantilism, the motto 'economy instead of war' ('Wirtschaft statt Krieg') was proclaimed for the first time in Austrian politics. It was meant to be a clear indication of the guidelines of the Austrian foreign policy for the upcoming century. The motto, however, never became the dominant maxim of Austrian politics because the ideological need of the Habsburg dynasty to continually maintain and magnify its power through war victories was still overwhelming. In any case, Austria introduced the system of prohibition in the trade in $1700 .^{6}$

In the context of the development of mercantilism, of absolutely crucial importance for Austria was the export of mercury and copper. The business with these raw materials was the most illustrative indicator of the mercantilist principles of economy in Austria. The mercury mine in Idrija was the most important of its kind in Europe. In the middle of the $18^{\text {th }}$ century this mine produced 170 tons of mercury per year, but already in 1786 the production increased to 584 tons. $^{7}$ The Netherlands was increasingly becoming a role model, but also a trading partner for Austria in the context of the development of its economy. To this end, the establishment of the first Austrian Western Company was in line with Dutch tradition. The development of the first factories in Austria began pretty soon and colonial goods were increasingly imported. However, very soon it became clear that the path of Austria to the desired mercantilist perfection could not be so easy. In the early $18^{\text {th }}$

\footnotetext{
2 Faber 1995: 42.

${ }^{3}$ Srbik 1907: 66.

${ }^{4}$ Rill 1992: 274.

${ }^{5}$ Petrović 1976: 27-28.

${ }^{6}$ Beer 1899: 3.

${ }^{7}$ Hösler 2006:78.
} 
century English East India Company began the import of Indian and Chinese mercury in order to destroy the Austrian monopoly in the sale of this precious raw material, which happened very drastically already in 1706. After this move the Dutch and English traders gained even greater rights in comparison to the Austrian politicians. Only in the last decades of the $18^{\text {th }}$ century Austria realized the existence of mechanisms for maintaining its monopoly on the production of mercury, which enabled a new large increase of production in Idrija.

In many respects the Požarevac peace treaty was a turning point for the development of the Austrian economy and trade in the region of Southeast Europe. The commercial contract signed on July 27 1718, six days after the peace agreement, was the basis for the expansion of Austrian trade. The contract, whose formal name was 'The Commercial and maritime contract with High Porte', explained all the details and aspects of trade in the Balkans and the Levant and determined the directions of maritime trade routes, the customs duties, payment of tolls, punishments for smuggling attempts, damage compensations, conflict resolutions, dealings in death cases, treatments in the event of a shipwreck, the freedom to profess religion for all traders from the area of the Habsburg Monarchy, etc. It was also agreed that the Austrian ships sailing through the Danube could drive their goods all the way to Vidin, where they were obliged to reload the goods on Turkish ships in case of possible further transport. ${ }^{8}$ During the peace negotiations in Belgrade in 1739 the Habsburgs were able to keep in force the decision deriving from this commercial contract, which was in fact their biggest success in the generally very poor outcome of peace talks in 1739 for the Austrian side. The provisions of trade agreements from 1718 were confirmed later on several occasions and remained in force until 1771, when Austria managed to sign a new, more favorable trade agreement. ${ }^{9}$

The development of industry and trade with the East at the beginning of the $18^{\text {th }}$ century was increasingly conducted via overland routes through Hungary. Not much later even Persia entered the Austrian sphere of economic interests. In addition to the English and the Dutch, a key role for the development of the Austrian trade towards East was in the hands of Armenian merchants. One of them who was particularly significant was Zechariah Sedgevic. ${ }^{10}$ After signing the peace treaty in 1718 and winning northern Serbia, Austria's abundant use of mines in Majdanpek and Oravice motivated a fast increase of copper ore export in the Ottoman Empire. ${ }^{11}$ Ottomans owned those mines during several previous centuries but always lacked adequate technical knowledge for their effective exploitation. Austria was quickly able to extract 80,000 tones of ore from these two mines and export the majority to the Ottoman Empire, so only through this export the total annual sales of about 360,000 ducats were injected into the new Austrian financial stream.

The trade circles from Vienna had successful examples of commercial activities and

\footnotetext{
8 Österreichisches Staatsarchiv, Abteilung Haus-, Hof- und Staatsarchiv (HHStA), Aufstellungsverzeichnis des Botschaftsarchivs Konstantinopel, A - Erste Gruppe, Kart. 70: Weisungen (Originale 1791-1799), Fasz. 1-407, Fol. 160-161.

${ }^{9}$ Faber 1995: 43.

10 Srbik 1907: 289-290.

${ }^{11}$ Steiermärkisches Landesarchiv, Graz, Landschaftliches Archiv, Antiquum, (StLA LAA), B1, Sch. 38 VW: Schuber betr. Türkenkriege.
} 
organizations in the territory of the Ottoman Balkans and the Levant right before them, especially a very successful French example and, later on, possibly the Dutch and the British examples. The Ottoman Empire was a logical destination for the first Austrian attempts for a significant accumulation of commercial capital. ${ }^{12}$ To this end, the first commercial company which was specialized in trade with the Ottoman Empire and the East in general was founded in Vienna in $1667 .{ }^{13}$ It was based in Istanbul, right next to the Austrian consulate, which was a clear signal that the Habsburg state decided how its diplomacy and trade should operate in strong cooperation. The Oriental Trading Company (Orientalische Handelscompanie), how the first Austrian merchant attempt was dubbed, did not last long in an increasingly fierce commercial competition in the Levant. The company was liquidated in 1683 with the beginning of the Austro-Turkish War. ${ }^{14}$

After the signing of the Požarevac peace treaty in 1718, Austria found new possibilities for the development of the trade with the Ottomans, so already in 1719 the Privileged Oriental Company (Privilegierte Orientalische Kompanie) was established to trade with the Ottoman Empire. This new eastern company allowed the monopolistic use of the Danube for young Austrian industry, which in the perspective of the economic environment led to the Balkan parts of the Ottoman Empire. ${ }^{15}$ This company made rapid progress and within a few years it was in possession of factories and warehouses in Vienna and Belgrade and then in Trieste and the Schwechat. ${ }^{16}$ In the beginning almost the entire company dealt only with the import and processing of cotton from the Ottoman Empire. However, under the pressure of naval forces of Great Britain and France and in terms of increased competition of Venetian and Greek traders, the company started to fall apart and finally closed in $1734 .^{17}$

The end of the wars with Turkey (1716-1718) and Spain (1717-1720) and the new prestigious political position of the Habsburg Monarchy led to attempts to create a new trading empire, which relied on the experience that Charles VI brought with him from Spain and on the actions of Spanish councilors, primarily in the sense of managing the existing commercial and maritime infrastructure in southern Italy and the Austrian Netherlands. On 18 March 1719 Charles VI issued a special decree on the general stimulation of trade. The Austrian ruler sought to create a port in his possession in the northern Adriatic, which would be a key site for commercial traffic between the Levant and the Far East on the one hand and Vienna, Prague, Budapest and other cities in the interior on the other. Already in 1719 the Venetian ambassador in Vienna Giovanni Priuli reported to his government that the Austrian emperor did not think about anything else except the creation of naval forces ('potenza Marittima'). In the euphoria of the war victory Viennese circles were hoping to be able to create a trading empire that would solve all the chronic financial problems of the complex Habsburg state within a few years. ${ }^{18}$

The key locations of the Austrian trade expansion in the northern Adriatic were to be

\footnotetext{
12 Srbik 1907: 291.

${ }^{13}$ Vocelka 2001:69.

${ }^{14}$ Faber 1995: 44.

15 Srbik 1907: 292.

${ }^{16}$ Vocelka 2001: 69.

${ }^{17}$ Rill 1992: 286-287.

${ }^{18}$ Faber 1995: 50.
} 
Trieste and Rijeka and the Kaiser gave them a status of free ports in 1719. ${ }^{19}$ Trieste had been in the possession of the Habsburgs since 1382 and Rijeka since $1471 .^{20}$ For an objective assessment of the potential positions of Rijeka and Trieste it is very important to understand the transport infrastructure that existed at that time. The 'Carolingian Road' ('Karoliner Straße'), which connected Karlovac and Rijeka, was completed in 1728 and had a great significance for the development of the Habsburg economy. ${ }^{21}$ However, the construction of the road that linked Karlovac and Senj, known as the 'Josephine road' ('Josefiner Straße'), started only in 1778, which meant that large parts of the Austrian Littorale, the including potentially significant port of Karlobag, were isolated from the interior. $^{22}$

In addition to the road network, during the $18^{\text {th }}$ century the Habsburgs ambitiously approached solving the problem of the construction of river channels and the regulation of riverbeds. After the Požarevac peace treaty and winning the whole area of Posavina and the Danube up to Negotin (in the sense of possessing both banks of the Danube), the Habsburg Monarchy was able to achieve an efficient system of commercial monopoly in the entire northern Balkans or to fully control the river system Danube-Sava between Zagreb and Negotin. In this sense, Austrians created plans for the regulation of linking the northwestern area of the Balkans with the regions of Central Europe and river channels and flows were particularly suitable for such projections. Upon the completion of the Carolingian road they had a possibility for transport of grain from the grain area of Timisoara and other parts of Southeast Pannonia upstream all the way to Zagreb and Karlovac and then through the rivers and channels further towards west, where it was exported to various European markets. ${ }^{23}$ The first plans to build a canal between the Danube and the Tisza were made in 1723 . Already in the following year the construction of the canal began but it was quickly abandoned due to a lack of funds. Subsequent efforts in building the whole transversal were made only in 1796, but even then there were no results. ${ }^{24}$ There were plans to connect the Danube and Rhine through canals with the Elbe, but there was no funding for their implementation. ${ }^{25}$ For the purposes of internal trade Austrians regulated rivers and streams in civilian areas of Croatia and Slavonia, especially the Drava River ${ }^{26}$ and its tributaries in southern Styria. ${ }^{27}$

Plans were not only concerned with the area of the Ottoman Empire. In the early 1720's Charles VI still did not give up the perspective of rule over Spain, which he so desired during the War of the Spanish Succession (1701-1714). Therefore, he was planning to create a trade route between the Austrian Netherlands, Spain and the Austrian Adriatic ports, which would connect and further integrate all the parts of his projected empire.

\footnotetext{
${ }^{19}$ Vocelka 2001: 69.

${ }^{20}$ Faber 1995: 37.

${ }^{21}$ Beer 1899: 4.

${ }^{22}$ Erceg 1966: 300-308.

${ }^{23}$ Roksandić 2007: 65-66.

${ }^{24}$ Petrović1978: 483.

25 Beer 1899: 2.

${ }^{26}$ Petrić 2005: 39-42.

27 'Saanregulierung 'StLA LAA, Miszellen, Sachgruppenreihe, Karton 263.
} 
Political events during the next decade and objective limits of the Habsburg ranges prevented the realization of such grandiose plans. Therefore, the Austrian ruler focused only on consolidating his positions on the Adriatic coast and in southern Italy. At the assembly of the government in 1728 the decision was made for Vice Admiral Eduard Deichmann, a Dane who was head of the Austrian Navy, to be sent to the Adriatic ports and also to Naples and Sicily in order to thoroughly inspect the situation there and the opportunities for the development of the fleet and trade. Deichmann was soon given the mission and later he submitted a detailed report to the emperor. ${ }^{28}$ He concluded that it was possible to achieve great results using the ports in the area he visited, but it was previously necessary to make large investments in the creation of adequate infrastructure or even to launch structural changes in the entire Austrian system of trade and economy. With the loss of possessions in southern Italy in 1735, the plans for increased trade in Sicily and Naples were completely deserted and only since then there was a full concentration of Austrian maritime efforts towards Trieste and Rijeka. ${ }^{29}$

The situation with the possibilities of development of Trieste and Rijeka was rather complex. Already mentioned was a lack of an adequate connection with the interior through roads. In addition, those ports lacked industrial backing that would encourage a greater development of commercial traffic. The population of the cities themselves and their surroundings were quite modest. However, in Vienna they knew that Venice was in a similar situation in the area of the northern Adriatic Sea that was not particularly representative in the Mediterranean framework and still Venice managed to become one of the most important ports in the whole of Europe for many centuries. ${ }^{30}$ Therefore, the Viennese circles were persistent in their efforts to create major ports from Trieste and Rijeka. Soon they began intensive investment in the construction of port infrastructure and plants for the processing of imported goods. ${ }^{31}$ Quick successes were achieved particularly with the refineries of sugar, wax and brandy in Rijeka, where the mass processing of imported sugar cane was carried out. At first, the inhabitants of the two port cities were delighted that the Kaiser and the state were investing so much in their ports and it seemed that great opportunities for instant profit have were coming, but then they were very unpleasantly surprised by centralist interventions of the emperor and with the regulation of trade in such a way that the state itself received much more than the residents of both ports. Therefore, soon there was an emergence of a real rebellion, which was manifested in a refusal to participate in the trade.

The Kaiser noted that the problems that appeared in Trieste and Rijeka were similar to the situations that were present in other parts of the Empire. The Austrian administrative system was managed with a considerable level of chaos and the powers of individual states and regional authorities in certain European administrative territorial units in general were not precisely regulated. There was a particularly vague relationship between the central

\footnotetext{
28 'Relazione datta all' Imperatore Carlo VI dal Vice Admiralio B. Deichmann in merito del stabilmento d' una Marina con la descrizione delli Boschi e Porti dei Regni di Napoli e di Sicilia cosi pure del Litorale Austriaco.'Faber 1995: 51.

${ }^{29}$ Vocelka 2001: 69.

${ }^{30}$ Beer 1899: 39.

${ }^{31}$ Gasser 1954: 127.
} 
government in Vienna and the government of Inner Austria, which since the $16^{\text {th }}$ century consisted of Styria, Carinthia, Carniola, Gorizia, Trieste and Istria, and whose economy functioned very poorly, mainly due to internal disunity. ${ }^{32}$ Based on that, immediately after gaining inner stabilization in 1720, Charles VI began the complex job of Austrian centralization. The centralization of administrative economic institutions was fully implemented by 1749 with the establishment of central economic affairs under the title 'Senior Commercial Directory' ('Kommerzien-Oberdirektorium') headed by Count Rudolf Chotek (1707-1771). ${ }^{33}$ Coastal areas comprised a separate administrative unit ('Litoralebezirk'). In 1752 Chotek personally led a commission that visited Trieste and Rijeka to be sure about their current capacities, but the findings were devastating. At this point, the market was much more modest than in the earlier stages during the 1720's and 1730 's. ${ }^{34}$

For the development of the Austrian maritime trade in the area east of the Adriatic Sea and in the whole Mediterranean a big problem was the constant pirate activity. Austrian commercial efforts were particularly threatened by pirates from the region of North Africa as well as from Ulcinj. After the Požarevac peace treaty in 1718 the pirate threat from Ulcinj was largely neutralized, but the pirates from the areas of Tunisia and Libya continued to attack ships under the Austrian flag. ${ }^{35}$ During the 1720's Austria launched an extensive campaign to stop pirate attacks which was largely controlled by a agreement mediated by the Ottoman authorities and signed in Tunis in 1725. What was the scope of importance of the victory of Eugene of Savoy over the Turks in the battles of 1697 and 1716-1717 was clearly indicated by the fact that he gained particular respect even across the Islamic world. When signing the agreement in 1725 regarding the protection of the trade between Austria and the deys who ruled Tunisia and Tripoli, who were nominally the vassals of the Ottomans, the admiration of the local rulers towards the famous Austrian army commander played a significant role. ${ }^{36}$

This, however, was not a permanent solution of the problems with North African pirates, whose prey always partly belonged to the Ottomans themselves, who were inclined to see the pirates' activities as a means of political pressure on the Habsburgs because formally the Ottomans did not have to respond to the Habsburg calls in the case of troubles with the African pirates. Knights of Malta and their warships were officially in charge of the defense of Austrian merchant ships from pirates, but did nothing in this respect, which is why Austrians would constantly distribute protest notes, usually without any results. ${ }^{37}$ When Tunisia and Libya were finally pacified to a greater extent, ${ }^{38}$ the key problem became Morocco because the local pirates sailed even as far as the Adriatic Sea in order to intercept

\footnotetext{
${ }^{32}$ Faber 1995: 65-68.

${ }^{33}$ Ibid.102.

34 Beer 1899: 39.

${ }^{35}$ Fendri 2005: 341.

${ }^{36}$ Rill 1992: 285.

37 HHStA, Staatenabteilungen, TürkeiII, Kart. 74: Weisungen, Berichte 1780, 1781 I-III, Fasz. Turcica1781 (Berichte) Jänner-März (1-364), Fol. 243-247.

${ }^{38}$ HHStA, Aufstellungsverzeichnis des Botschaftsarchivs Konstantinopel, A - Erste Gruppe, Kart. 70: Weisungen (Originale 1791-1799), Fasz. 1-407, Fol. 191.
} 
Austrian ships. ${ }^{39}$ In addition, pirates from Libya and Tunisia further usually attacked under the Moroccan flag because both were now accountable to Austria if attacks happened under their flags. ${ }^{40}$ In this context the turning point occurred in 1782, when a special Moroccan delegation led by Mohammed Abdulmalek came to Vienna. Upon his return to Morocco he brought a new companion from Vienna. Austrian linguist and translator Franz von Dombay, who completed his studies at the Oriental Academy, arrived in Tangier on 21 August 1783 and officially opened the Austrian consulate. ${ }^{41}$ Immediately after that act the relations between Austria and the Moroccan pirates became much more settled. ${ }^{42}$ The problems, however, still persisted. Despite effective diplomacy, the Austrian naval trade policy could not function properly primarily due to the lack of an adequate naval fleet that would protect merchant ships from pirate attacks. ${ }^{43}$ Only with the gain of Venice and part of its flee in 1797 did Austria acquire a basis to adequately protect its trade so the naval activities in the $19^{\text {th }}$ century were much safer and more profitable in the area of the Mediterranean Sea.

Despite all attempts of Habsburgs during the $18^{\text {th }}$ century Trieste and Rijeka did not become large ports which would significantly contribute to the development of trade and economy in general. Besides, the Austrian trade with the Ottoman Empire itself did not progress at a pace that had been planned. On 2 February 1751 Penckler, Austrian Internuncio in Istanbul, sent a detailed report on the state of the Austrian trade with the Ottoman Empire to Count Chotek, president of the new central economic services of the Viennese government. In this report Penckler concluded that, especially from the perspective of Istanbul, 'the German trade' did not exist on the territory of the Ottoman Empire. ${ }^{44}$ The only Austrian items that were constantly in need on the Turkish market were the products of Czech crystal workshops, which had already had great importance in the whole of Europe for centuries. In Istanbul it was absolutely impossible to find a dealer from the Habsburg Monarchy. Products from Styria and other areas came to the Turkish market just over Venetian intermediaries.

The degree of development of the Austrian maritime trade with the Ottoman Empire was very illustrative in the statistics of maritime transport in Ottoman ports during the $18^{\text {th }}$ century. In the period from 1756 to 1776 French ships were accounted for $54.4 \%$ of all European ships that docked in Izmir, one of the largest commercial ports in the entire Ottoman Levant. This fact was a clear indicator of absolute French dominance in the European trade with the Ottomans, as well of the political position that France had at the Porte. In the same period $15.4 \%$ of all European ships were Venetian, which meant that the Venetian Republic still retained a considerable influence in the Levantine trade despite the general economic and political decline. The third place in the maritime trade routes was occupied by the Dubrovnik Republic with $11.8 \%$, followed by the Netherlands with $8 \%$ and so on. Austria did not even exist in the statistics of ships that docked in Izmir. ${ }^{45}$

\footnotetext{
${ }^{39}$ Gasser1983: 171.

40 Beer 1899: 90.

${ }^{41}$ Schmidt1999: 235-238.

${ }^{42}$ Matsch1986:262.

43 Beer 1899: 80.

44 „....sozusagen ein deutsches Commercium dermals hier nicht existiere. “ Gasser 1954: 121.

${ }^{45}$ Panzac 1985: 136.
} 
In April and May 1775 Emperor Joseph II personally visited Trieste, Rijeka and all other areas of the Austrian Adriatic coast in order to be sure of their economic potential. Arriving to Rijeka from Karlovac he found the circumstances to be very unpleasant. He noticed that the port was in such a bad shape that the few ships that transported sugar cane and sugar could not even find a place to dock. The population was so poor that the entire city often lacked bread and no one ever thought of the development of trade. ${ }^{46}$ After his return to Vienna, Joseph II issued a decree to dissolve this separate administrative unit which comprised the coastal areas and to award Rijeka to the Hungarian Kingdom. With the support of the Hungarian party at the Viennese court led by Count Theodore Batthány the decision was officially proclaimed on 3 January 1776. Thus, Rijeka, Bakar and the surrounding territory ceded to the administration of the Kingdom of Hungary as its only coastal area. Karlobag was attached to the Military Frontier. ${ }^{47}$ Trieste was somewhat more significant than Rijeka and significant commercial projects were initiated on several occasions at the Trieste port, such as the establishment of a separate company for trade with Egypt on 2 December $1782 .{ }^{48}$ But even those projects were mostly short-lived.

All measures taken in the end did not significantly contribute to the development of maritime trade with the Ottoman Empire. Trieste and Rijeka remained very modest ports in the Adriatic context in comparison with Venice or Dubrovnik. Only in the upcoming decades, when Austria somewhat unexpectedly got hold of the Venetian and Dubrovnik Republics (in 1797 and 1813, respectively) and of Venice and Dubrovnik as the largest and most important ports of the Adriatic, the right circumstances were finally created for the expansion of the Habsburg maritime trade in the Levant.

All attempts for trade organizations in the Balkans and the Levant during the $18^{\text {th }}$ century were to be only part of the great Austrian project of trade development with the whole of Asia. Following the example of the East India Companies, which in England and the Netherlands existed since 1600 and 1602 respectively, Charles VI tried to create the Austrian equivalent. The basis for such aspirations was the possession of the port in Ostend (Oostende) on the Atlantic coast of the Austrian Netherlands. The use of Antwerp was disabled because under the decisions of the Utrecht peace treaty from 1713 there was general prohibition from using of the River Scheldt for commercial traffic from the Atlantic. ${ }^{49}$ Thus, under the pressure from the Netherlands and Great Britain the once wealthy city on the Scheldt delta was permanently unable to evolve into a meeting place for large retail revenue for the Habsburg Monarchy. To avoid high monopolistic prices of colonial goods that they had to pay mainly to the Dutch and to dealers from Hamburg, ${ }^{50}$

46 ,...daß nicht einmal die Schiffe, die Zucker bringen, eine Landung mehr finden können, gar kein Haven vorhanden ist, und alles von Hunger stirbt und die ganze Stadt oft kein Brod hat, auch nichts in der Handlung gemacht wird.“ HHStA, Familienarchiv, Hofreisen, Kart. 9: 1775.

${ }^{47}$ Faber 1995: 232.

${ }^{48}$ Gasser 1954: 127.

${ }^{49}$ It was actually a confirmation of the decision already made during the Peace of Westphalia in 1648, under which river Scheldt was closed for maritime traffic during the period of Spanish rule over Antwerp. Israel 1998: 975.

${ }^{50}$ Tradesmen from Bohemia and other Northern Habsburg lands used to have traditionally good relations with Hamburg. Therefore, they were allowed to further enjoy the possibilities of supply from this German port. Faber 
Austrians from Ostend went on to create their own colonies in India and started a business project called Ostend Company (Oostendse Compagnie).

Austria's first ships were headed to India in 1715 and the first colony in Madras (present-day Chennai) was established in 1719. Kaiser decided to put Ostend Company under the full state patronage in December 1722 and enabled the project to have a vast share capital of six million guilders. ${ }^{51}$ After that the company achieved increasing success in global trade with India and other parts of Asia in each subsequent year. Mercury, lead, iron and fabric were exported to India and on the other hand many goods were imported, mainly cotton, silk (especially from Bengal), diamonds, porcelain and spices. Tea was mainly imported from Canton in China. ${ }^{52}$ The Austrian company became a surprisingly significant competition to British and Dutch traders. In this context, the question of destiny of Ostend Company was increasingly associated with the political decisions of the Western powers about the recognition of Pragmatic sanctions or requirements that the Habsburg court had to meet in order to receive such a recognition. Under pressure from the demands of Great Britain and the Netherlands on 31 May 1727 the work of the Company was suspended for seven years. ${ }^{53}$ It was soon clear that this was not enough for traditional maritime forces and Charles VI, in agreement with the United Kingdom of 16 March 1731, agreed to completely abolish Ostend Company with the permission of the possibility of holding a minimum trade with India. In this way the Habsburg ruler destroyed most profitable Austrian trading company throughout the $18^{\text {th }}$ century. Only nine years later, with the outbreak of the War of Austrian heritage, the political decision, which was the reason for the company liquidation, no longer meant anything. All subsequent attempts to revitalize the company, especially in the era of Joseph II, did not yield the desired results except in one case and only in a limited range.

With the new wave of flexibility inside the Austrian leadership, especially with a greater emergence of Joseph II and a significant influence of chancellor Kaunitz, some possibilities opened again. The war between Great Britain on the one and France, Spain and Netherlands on the other side (regarding the American independence, 1774-1783) was very suitable for the new neutral role of Austria. Tradesman and adventurer William Bolts (17391808) became a key person for the development of Austrian trade in the Asian region during the 1770's. He was one of the most successful and most capable employees of England's East India Company in Bengal, India in the period from 1759 to 1769. Earlier he used to polish his skills in the diamond trade in Lisbon. After a number of successful years, when he came into conflict with certain figures from and around the top of the company, primarily because of the way he managed to amass his personal fortune (illegal trade in diamonds) he was fired by the company, violently arrested, and then sent by ship back to England in chains. Immediately after arrival in England and prompt liberation (for he was not charged by the British state authorities, but by the authorities of the East India Company) Bolts set off a big counter-propaganda, and soon released a major report which he described in detail

1995: 97.

${ }^{51}$ Vocelka 2001: 70-71.

${ }^{52}$ Israel 1998: 981.

${ }^{53}$ Rill 1992: 258. 
a mode of action of the company in the area of Bengal and the system of exploitation of the local population, which led to the creation of a quasi-state system by the company, not only in the context of Indian states, but also in relations towards Great Britain. By doing so Bolts managed to reveal a large spinning wheel of bribery and corruption. His book from $1772^{54}$ became an instant bestseller and the East India Company suffered extensive damage not only in the field of bad publicity.

On the other hand Bolts gained enormous popularity and the possibility that his expertise acquired in the ten years of Indian experience was soundly desired by the majority of British competitors. With the intervention of the Austrian ambassadors in London (Ludovico di Belgiojoso) and The Hague (Thaddäus von Reischach), Bolts got in touch with the Vienna court and already in the fall of 1774 he was in Vienna for the negotiations about the establishment of the Austrian version of the East India Company. ${ }^{55}$ Similar to the situation when, in exchange for an alliance with Britain and the Netherlands under the contract from 1731, Austria was ready to liquidate the so-called Ostend Company, which the Vienna court orchestrated from the region of contemporary Belgium, Austria was deprived of opportunities to organize the trade from Belgium with Asia. Bolts came up with the idea to organize trade from the Austrian ports on the Mediterranean. In the foreground of idea was the port of Trieste, but Livorno (Leghorn) was of huge significance as well, because Tuscany was a kind of an Austrian "secundogenitur".

So began the process of creating the Austrian East India Company, which was fully embodied with the great expedition to India, which William Bolts led from Livorno in 1776. ${ }^{56}$ During next ten years Bolts formed two different companies in succession that carried the names 'Société Imperial asiatique de Trieste et Anvers' and 'Société asiatique de Trieste' respectively, based in Trieste, Ostend and Antwerp (because his key financiers were the Antwerp bankers and traders led by Charles Proli), ${ }^{57}$ trying to break the British and Dutch monopoly on the trade in South and Southeast Asia and further trying to reach the base for trade with China, Japan and even with the north-west coast of North America. ${ }^{58}$

In the end his efforts were not fruitful in an attempt to make a decisive breakthrough and the complete process was inadvertably halted for Austria with the emergence of the French revolution and subsequent wars in Europe (1792-1815). ${ }^{59}$ Still, this episode with William Bolts was a hard testimony about the Austrian possibilities for efficient positioning in the Asian market under certain circumstances and about the general potential that was accumulated inside the Asian trade for Austria, the state that was traditionally so much concentrated exclusively on Central European affairs. Connections established with some parts of the world were unique in the perspective of the Habsburg history and were never again established in that context until the end of the dynastic rule in 1918.

\footnotetext{
54 Bolts 1772.

${ }^{55}$ Hallward 1920.

${ }^{56}$ HHStA, Staatenabteilungen, England, Kart. 117: Berichte 1777, Fasz. Korr. 1777. (Belgioso).

${ }^{57}$ Houtman-De Smedt1983.Charles Proli commited suicide in 1786 because of financial desaster of efforts in which he invested large sums.

${ }^{58}$ Wanner 2008: 22.

${ }^{59}$ Bolts1787.
} 


\section{REFERENCES:}

Österreichisches Staatsarchiv, Abteilung Haus-, Hof- und Staatsarchiv, (HHStA):

- Aufstellungsverzeichnis des Botschaftsarchivs Konstantinopel, A - Erste Gruppe, Kart. 70:

Weisungen (Originale 1791-1799), Fasz. 1-407, Fol. 160-161, 191.

- Staatenabteilungen: Türkei II, Kart. 74: Weisungen, Berichte 1780, 1781 I-III, Fasz. Turcica 1781 (Berichte) Jänner-März (1-364), Fol. 243-247; England, Kart. 117: Berichte 1777, Fasz. Korr. 1777. (Belgioso)

- Familienarchiv, Hofreisen, Kart. 9: 1775.

Steiermärkisches Landesarchiv, Graz, Landschaftliches Archiv, Antiquum, (StLA LAA):

- B1, Sch. 38 VW: Schuber betr. Türkenkriege

- Miszellen, Sachgruppenreihe, Karton 263.

References:

Beer, A. 'Die österreichische Handelspolitik unter Maria Theresia und Josef II.', Archiv für österreichische Geschichte, 86, 1899, 1-204.

Bolts, W. Considerations on India affairs: particularly respecting the present state of Bengal and its dependencies, Bengal (India): J. Almon, 1772.

Bolts, G. Recueil de pièces authentiques, relatives aux affaires de la ci-devant Société impériale asiatique de Trieste, gérées à Anvers, Antwerpen, 1787.

Erceg, I. 'Der Merkantilismus in Kroatien. Die Handelspolitik des Habsburgerstaates im 18. Jahrhundert mit besonderer Berücksichtigung Ungarns und seiner Nachbarländer', Österreichische Osthefte, 8, 1966, 300-308.

Faber, E. Litorale Austriaco. Das österreichische und kroatische Küstenland 1700-1780, TrondheimGraz: Schriftenreihe des Historischen Instituts, Nr. 5, Veröffentlichungen des Steiermärkisches Landesarchives 20, 1995.

Fendri, M. 'Die Habsburgermonarchie und die „Barbaresken“. Die Gesandschaft des Jussuf Khodscha in Wien (1732/1733) als Nachspiel des ersten österreichisch-tunesischen Friedensvertrag von 1725', in: M. Kurz (eds.), Das Osmanische Reich und die Habsburgermonarchie, WienMünchen: R. Oldenbourg 2005, 341-358.

Gasser, P. 'Österreichs Levantehandel über Triest 1740-1790', Mitteilungen des Österreichischen Staatsarchivs, 7, 1954, 120-130.

'Handelsversuche mit Spanien und die Probleme der österreichischen Schifffahrt in den Jahren 1750-1780.', Mitteilungen des Österreichischen Staatsarchivs, 36, 1983, 150-187.

Hallward, N.L., William Bolts, A Dutch Adventurer under John Company, Cambridge: Cambridge University Press, 1920.

Hösler, J. Von Krain zu Slowenien. Die Anfänge der nationalen Differenzierungsprozesse in Krain und der Untersteiermark von der Aufklärung bis zur Revolution 1768 bis 1848, München: R. Oldenbourg Verlag, 2006.

Houtman-De Smedt, H. Charles Proli, Antwerps zakenman en bankier, 1723-1786. Een biografische en bedrijfshistorische studie, Bruxelles, 1983.

Israel, J. I. The Dutch Republic. Its Rise, Greatness, and Fall 1477-1806, Oxford-New York: Clarendon Press, 1998.

Matsch, E. Der Auswärtige Dienst von Österreich(-Ungarn) 1720-1920, Wien-Köln-Graz: Böhlau, 1986.

Panzac, D. La peste dans l'Empire Ottoman 1700-1850, Leuven: Peeters, 1985.

Petrić, H. 'Utjecaj rijeke na pogranična naselja. Primjer rijeke Drave u 18. i 19. stoljeću', Ekonomska 
i ekohistorija, Vol. I, broj 1, 2005, 37-62.

Petrović, N. „O nekim otvorenim i spornim pitanjima kolonizacije srednjeg Podunavlja u XVIII veku“, Jugoslovenski istorijski časopis, 1-2/1976, 1976, 19-41.

. Plovidba i privreda srednjeg Podunavlja u doba merkantilizma. Izgradnja kanala DunavTisa i napori za povezivanje srednjeg Podunavlja sa Jadranskim morem krajem 18. veka, Beograd: Istorijski institut, 1978.

Rill, B. Karl VI. Habsburg als barocke Großmacht, Graz-Wien-Köln, 1992.

Roksandić, D. 'Posavska krajina/granica od 1718. do 1739. godine', Ekonomska i ekohistorija, Vol. III, broj 3, 2007, 62-82.

Schmidt, J. 'Franz von Dombay, Austrian Dragoman on the Bosnian Border 1792-1800', in: M. Köhbach , G. Procházka and C. Römer (eds.), Acta Vienensia Ottomanica, Akten des 13. CIEPO-Syposiums vom 21. bis 25. September 1998 in Wien, Wien, 1999, 235-238.

Srbik, H. R. von. Der staatliche Exporthandel Österreichs von Leopold I. bis Maria Theresia. Untersuchungen zur Wirtschaftsgeschichte Österreich in Zeitalter der Merkantilismus, WienLeipzig, 1907.

Vocelka, K. Österreichische Geschichte 1699-1815. Glanz und Untergang der höfischen Welt. Repräsentation, Reform und Reaktion im habsburgischen Vielvölkerstaat, Wien: Ueberreuter, 2001.

Wanner, M. 'Imperial Asiatic Company in Trieste-The Last Attempt of the Habsburg Monarchy to Penetrate East Indian Trade, 1781-1785', in: 5th International Congress of Maritime History, Royal Naval College, Greenwich, 23-27 June 2008, Greenwich, 2008, 1-29.

БОРО БРОНЗА

Универзитет у Бања Луци, Филозофски факултет, Одсек за историју

\section{АУСТРИЈСКА ТРГОВИНА ПРЕМА ОСМАНСКОМ ЦАРСТВУ И АЗИЈИ ТОКОМ 18 ВИЈЕКА}

\section{Резиме}

Са завршетком турбулентног процеса великих географских открића током 15. и 16. вијека, успостављен је, те у правом смислу и развијен свјетски привредни систем, који је у доминантној мјери почивао на трговини. У 18. вијеку, односно у његовој другој половини, пред почетак индустријске револуције, тај систем је доживио свој врхунац. Главни протагонисти система су биле традиционалне поморске силе, у првом реду Шпанија, Португал, Холандија, Француска и Енглеска, чије су флоте с временом пропорционално расле и омогућавале експанзију на свим океанима и континентима. С протоком времена наведена диверсификација круцијалних протагониста унеколико се интензивирала, при чему су примарне европске колонијалне силе, Шпанија и Португал, постепено падале у други план, док су неке нове сјеверне и источне европске силе повећавале свој удио у глобалној флуктуацији роба и добара, првенствено на простору Индије, али и другим дијеловима Азије. Уз Русију, Пруску, Шведску и Данску, у све већој мјери на свјетској трговачкој сцени је расла и улога Аустрије.

На самом почетку 18. вијека Аустрија је још увијек углавном била само посматрач, јер је њено дјеловање и на политичком и на трговачком плану било традиционално изразито континентално. Међутим, с временом је потенцијал акумулације трговачког капитала постајао све привлачнији и у хабзбуршким калкулацијама, те је и двор у Бечу убрзано улагао све улагао све веће напоре како би повећао свој проценат у оквирима глобалне подјеле трговачке добити. 
У настојању да се што ефикасније позиционира, Аустрија је 1714. године извршила темељну реорганизацију Дворске коморе. Реформа је почивала на ефикасној децентрализацији, при чему су новонастали комисиони посједовали велики степен независности. Таква административна основа је омогућила нове димензије аустријске експанзије према истоку и југоистоку с протоком 18. вијека.

Уз нове начине постављања према Османском Царству, те суфиците који су остваривани након стицања политичког и економског монопола са закључењем врло повољног Пожаревачког мира 1718. године, ишла је и све успјешнија трговина према удаљенијим дијеловима Азије. Осим дјеловања хабзбуршке Оријенталне компаније из Остендеа у Фландрији (1719-1731), посебно интересантна епизода развоја аустријске дипломатије и трговине на простору Индије и других дијелова Азије односила се на активност Вилхелма Болтса, првенствено у раздобљу 1776-1786. У оквирима Болтсовог покушаја Аустрија се сусрела са свом силином британског монопола који се све више учвршћивао на простору Индије и Јужне Азије, тако да су дугорочни резултати остали релативно скромни, нарочито због драматичног пресјека свих напора са избијањем система ратова у Европи након Француске револуције (1792-1815). Ипак, резултати који су постигнути и генерално врло ефикасан начин приступа указивали су на изузетне могућности које су на плану развоја трговине Аустрије са Азијом стајале пред Бечким двором у условима повећане флексибилности и инвентивности, чиме се посебно карактерисала владавина Јосипа II.

Кључне речи: Аустрија, Османско царство, Азија, Индија, привреда, трговина, меркантилизам, жива, Трст, Ријека, Вилхелм Болтс. 